\title{
Effect of Three Husbandry Systems on Environmental Impact of Organic Pigs
}

\author{
Gwendolyn Rudolph ${ }^{1}$, Stefan Hörtenhuber ${ }^{1, *}$, Davide Bochicchio ${ }^{2}$, Gillian Butler ${ }^{3}$, \\ Roland Brandhofer ${ }^{1}$, Sabine Dippel ${ }^{4}$, Jean Yves Dourmad ${ }^{5}{ }^{1}$, Sandra Edwards ${ }^{3}{ }^{\circ}$, \\ Barbara Früh ${ }^{6}$, Matthias Meier ${ }^{7}$, Armelle Prunier ${ }^{5}\left(0\right.$, , Christoph Winckler ${ }^{1}$, Werner Zollitsch ${ }^{1}(\mathbb{D}$ \\ and Christine Leeb ${ }^{1} \mathbb{D}$ \\ 1 Department for Sustainable Agricultural Systems, University of Natural Resources and Life Sciences Vienna, \\ 1180 Vienna, Austria; gwendolyn.rudolph@fibl.org (G.R.); r.brandhofer@gmx.at (R.B.); \\ christoph.winckler@boku.ac.at (C.W.); werner.zollitsch@boku.ac.at (W.Z.); christine.leeb@boku.ac.at (C.L.) \\ 2 Research Centre for Animal Production and Aquaculture, Council for Agricultural Research and Economics, \\ 41100 Modena, Italy; davboch@hotmail.com \\ 3 School of Natural and Environmental Sciences, Newcastle University, NE1 7RU Newcastle Upon Tyne, UK; \\ gillian.butler@newcastle.ac.uk (G.B.); sandra.edwards@newcastle.ac.uk (S.E.) \\ 4 Institute of Animal Welfare and Animal Husbandry, Federal Research Institute for Animal Health, \\ 29223 Celle, Germany; sabine.dippel@fli.de \\ 5 Physiology of Adaptation, Animal Nutrition and Health, INRA, 35590 Saint-Gilles, France; \\ jean-yves.dourmad@inra.fr (J.Y.D.); armelle.prunier@inra.fr (A.P.) \\ 6 Department of Extension, Training and Communication, FiBL, 5070 Frick, Switzerland; \\ barbara.frueh@fibl.org \\ 7 Department of Socio-Economic Sciences, FiBL, 5070 Frick, Switzerland; matthias.meier@fibl.org \\ * Correspondence: stefan.hoertenhuber@boku.ac.at; Tel.: +43-1-47654-93229
}

Received: 29 September 2018; Accepted: 17 October 2018; Published: 20 October 2018

\begin{abstract}
This study examined the environmental impact of the three common organic pig husbandry systems, indoor $(n=24)$, partly outdoor $(n=30)$, and outdoor $(n=10)$, in eight European countries. Global warming (GWP), acidification (AP), and eutrophication potential (EP) was assessed per $1000 \mathrm{~kg}$ pig live weight on 64 farrow-to-finish pig production chains (cradle to farm gate). GWP, AP, and EP varied greatly, and the most important source was feed production, followed by housing. GWP did not differ between systems $(p=0.934)$, but AP in indoor systems and EP in outdoor systems were higher than in partly outdoor systems ( $p=0.006$ and $p=0.010$, respectively). The higher AP in indoor systems can mainly be explained by $\mathrm{NH}_{3}$ arising from manure spreading, while $\mathrm{PO}_{4}$-eq arising from feed consumption and emissions on pasture accounted for the higher EP in outdoor systems. Associations of farm characteristics with (reduced) environmental impacts were mainly found for $\mathrm{AP}$ and EP, and included: (Increasing) farm size, numbers of piglets born and weaned per litter, (bought-in) mineral feed, and high-protein by-products, the latter probably connected to beneficial effects of appropriate dietary digestible lysine levels and feed conversion ratio. Increasing carcass weights and dietary cereal proportions were associated with higher environmental impacts. Overall, variation was mostly higher within than between systems, and measures to mitigate environmental impact were identified.
\end{abstract}

Keywords: life cycle assessment; global warming potential; acidification potential; eutrophication potential; cradle to farm gate; indoor; outdoor 


\section{Introduction}

Together with the general growth of organic farming in many European countries, organic pig farming has expanded in recent decades [1]. However, the pig meat sector still ranks relatively low in organic product sales, particularly in comparison to the sheep and bovine sectors [2].

Climate change as well as animal health and welfare are among the most current issues in the public and scientific debate concerning livestock [3-6]. Likewise, sustainability and its assessment, covering environmental, economic, and social aspects, have gained importance in recent years. For instance, the Sustainability Assessment of Food and Agriculture systems (SAFA) Guidelines [7] have been developed as an international reference document to allow for consistent analyses and assessments despite the complexity of sustainability. According to the SAFA guidelines, sustainability consists of four dimensions: Good governance, environmental integrity, economic resilience, and social well-being. In the dimension of environmental integrity, the following themes are addressed: Atmosphere, water, land, materials and energy, biodiversity, and animal welfare.

Livestock production exerts severe impacts on soil, water, and air quality due to the related emissions [4]. The world's livestock sector contributes $14.5 \%$ of global greenhouse gas emissions, with pigs accounting for $9 \%$ of overall livestock-related emissions [5].

The life cycle assessment (LCA) provides a valuable and consistent methodological framework to quantify the environmental impact within the life cycle of a product [8]. Hence, several LCAs have been conducted in recent years to quantify the environmental impact, mainly greenhouse gas emissions (global warming potential, GWP), acidification potential (AP), and eutrophication potential (EP), of animal husbandry systems [9-11]. Until now, due to high $\mathrm{CH}_{4}$ emissions from enteric fermentation, ruminants have mainly been in the focus, but in light of the high consumption of pork and pork products in the European Union, pork production must also be considered.

Since pig production is dominated by non-organic production systems, most studies cover conventional systems [4]. As for most LCA studies dealing with pigs, for organic pig production, which is still comparatively small-scale, but nevertheless rapidly developing, only a few modelling studies are available [12-14]. Only a few studies have conducted an LCA using individual farm data [15], and even fewer have been based on a considerable number of organic farrow-to-finish pig farms.

As organic pigs are produced according to the general principles of organic farming [16], national, and international regulations (e.g., EC Nos. 2018/848 and 889/2008, $[17,18]$ ) as well as private standards [19], organic pig farms have been treated as a uniform system in most studies. However, it has recently been shown that organic pig farms in Europe can clearly be distinguished into three main "husbandry systems": Pigs may be kept completely outdoors in paddocks on pasture, as in most UK and Italian farms, or indoors, with access to a limited concrete outside run, as in most farms in German speaking countries. Furthermore, both systems, indoor and outdoor, may be combined on one farm for different production stages or during different seasons, as is common, for example, in Denmark or France [1,20].

Keeping pigs on pasture has a potentially higher risk regarding nutrient losses $[14,21]$ compared to pigs kept indoors, where manure is collected, stored, and spread in a controlled way on fields. Furthermore, due to a more controlled (thermal) environment, pigs kept indoors might have better feed conversion ratios and a higher number of piglets weaned, both reducing the environmental impact [22,23].

Besides the effects on environmental impact caused by the husbandry system, as described above, other important influencing factors contribute to variation. As LCA data from 27 conventional farms show, other factors, such as diet characteristics (e.g., level of by-products), influence the environmental impacts [9]. Therefore, also for organic pig production, individual farm data are needed to describe and quantify the potential influence of the three husbandry systems as well as those individual farm characteristics with potential impact on the environment. 
Consequently, the present study aims to deliver first indications to support strategic decisions in the organic sector (policy makers, extension services) or at the farm level (farmer). The analysis focuses on the environmental impact of three common organic pig husbandry systems, indoor (IN), partly outdoor (POUT), and outdoor (OUT), regarding their GWP, AP, and EP. Furthermore, farm characteristics influencing these impacts are assessed by cluster and correlation analysis. Two hypotheses are tested: (1) The null hypothesis that there are no differences between husbandry systems regarding the environmental impact (GWP, AP, EP), and (2) that there are specific farm characteristics, which explain variation independent from the husbandry systems.

\section{Materials and Methods}

\subsection{Overall Study Design and Participating Farms}

The present assessments are based on data collected during visits to 74 organic pig farms, representing three different husbandry systems, IN (34 farms), POUT (28 farms), and OUT (12 farms), in eight European countries (Austria, Czech Republic, Denmark, France, Germany, Italy, Switzerland, and the United Kingdom) during 2012 and 2013 (see Supplementary Materials). In each country, all assessments were carried out by one trained observer. All observers attended a common training course to standardize assessments. The different husbandry systems were defined as described in Table 1.

Table 1. Definition of the three organic pig husbandry systems: IN, POUT, and OUT.

\begin{tabular}{cll}
\hline System & Abbreviation & \multicolumn{1}{c}{ Definition $\mathbf{1 , 2}^{\mathbf{2}}$} \\
\hline indoor & IN & $\begin{array}{l}\text { Pigs live in buildings with access to a concrete outside run, or to an } \\
\text { outside run on soil, which is a small sacrifice area for permanent pig use } \\
\text { and not integrated into crop rotation. }\end{array}$ \\
\hline $\begin{array}{c}\text { partly } \\
\text { outdoor }\end{array}$ & POUT & $\begin{array}{l}\text { Pigs spend part of the production cycle indoors and part outdoors. } \\
\text { There can be at least one production stage (dry sows, lactating sows, } \\
\text { group suckling, weaned piglets, or finishing pigs) outside while the rest } \\
\text { is housed, or pigs spending part of the year outside and the rest indoors } \\
\text { (seasonal housing). }\end{array}$ \\
\hline outdoor & OUT & $\begin{array}{l}\text { Pigs live permanently outdoors in paddocks with shelter (temporary } \\
\text { hut or permanent building), but unrestricted access to the soil. The } \\
\text { paddock is usually integrated as pasture in a crop rotation. }\end{array}$ \\
\hline
\end{tabular}

\footnotetext{
${ }^{1}$ Weaned piglets kept in an enclosure directly on soil in fields are considered OUT if only the lying area is roofed, and considered IN if the entire enclosure is roofed; ${ }^{2}$ if only a small percentage of the animals $(<10 \%$ in herds of up to 300 pigs in total, or $<5 \%$ in larger herds) are kept in a different husbandry system, the farm is classified according to the dominant system.
}

Organic pig farms were recruited through farm advisors, producer associations, agricultural journals and their websites, or personal contacts. Farms had to be certified organic for at least two years and preferably combined farrow-finish farms with more than 20 sows and 100 finishing places. Recruitment was also based on the type of husbandry system, as the objective was to compare the three different organic pig systems.

As this study investigated the environmental impact of pork production from piglet production until slaughter, production chains from farrowing to finishing (PC) were the statistical unit. This comprised 64 PCs (24 IN, 30 POUT, 10 OUT), which were either farrow-to-finish farms (15 IN, 24 POUT, 9 OUT) or which were formed of co-operating farrowing-only and fattening-only farms $(6,6$, and 1 IN, POUT and OUT PCs, respectively). Additionally, for three other PCs (IN), data from the co-operating farm was not available during the study, and the average of the other farms was then used for the missing part of the PC. For each individual PC, environmental impact categories were calculated as outlined below, with pairs of farrowing-only and fattening-only farms being treated as farrow-to-finish farms. 
Based on the literature $[10,15,24]$ and expert knowledge, a standardized on-farm assessment protocol for use on a tablet computer was developed and a supplementary dictionary was translated to the languages of involved countries. The final protocol included an interview with the farm manager, the analysis of farm records, and direct observations. It was structured in thematic sections, including the following parameters:

- Farm and manure management, description of husbandry systems;

- productivity data and medicinal treatments (records);

- $\quad$ land use (crop production);

- diet composition and dietary nutrients contents; and

- provision of resources (husbandry system) for weaners (defined as pigs from post weaning with at least six weeks until transfer to a fattening unit with approximately 12 weeks), fatteners (includes the growing and finishing phase from approximately $30 \mathrm{~kg}$ to slaughter), pregnant, and lactating sows (direct observations)

The PC-specific data used in the present study are based on inventory data either collected on the day of visit or covering a period of 12 months prior to the farm visits.

\subsection{Scope of the Study and Life Cycle Assessment Methodology}

\subsubsection{System Boundaries, Functional Unit, and Allocation Approach}

As the study focused on pig farming systems, transport, slaughter, and processing of the carcasses were not included. The system boundaries were defined as cradle-to-farm gate, in this case from piglet birth to pigs ready for slaughter, and included relevant farm inputs needed for this (e.g., electricity, transport-related (fossil) energy for feedstuffs, etc.). While the energy-gain from co-digestion of manure in biogas plants was not considered (as not directly related to the pig unit), digestion-related emission factors were used to derive results from co-digestion of manure. Following LCA-related guidelines, such as PAS2050 [25], for the assessment of greenhouse gas emissions, emissions from the construction of farm infrastructure (e.g., livestock barns, machinery, farm buildings) were excluded from the LCA. Furthermore, veterinary treatments and inputs, such as cleaning agents and disinfectants, were not considered within the system boundaries as a lower use is assumed in organic farming [26]. The functional unit was $1000 \mathrm{~kg}$ of live weight of fattening pigs leaving the farm (live weight at slaughter), including culled sows. The live weight at slaughter was calculated based on carcass weight records using an equation used for organic pigs from different countries [27]. An energy allocation approach was used throughout the study, for instance, for feedstuffs' emission factors.

\subsubsection{Environmental Impacts Considered, Data Sources, and Methodological Details}

GWP (100 year-horizon) [28], AP, and EP were calculated using a modified version of an Excel tool developed by Dourmad et al. [15]. Emissions were calculated from measured as well as modelled data per individual PC, using typical emission factors for livestock-related emissions [29]. For EP and AP from the pig unit and feed production, characterization factors were used as described in [8] and [30]. Gaseous emissions from animal husbandry and manure storage were calculated for $\mathrm{NH}_{3}$, $\mathrm{N}_{2} \mathrm{O}$, and $\mathrm{NO}_{X}$ as well as $\mathrm{CH}_{4}$ based on [28,29,31] and other sources as described in [15].

Calculations for nitrogen $(\mathrm{N})$ and phosphorous $(\mathrm{P})$ retention and excretion have been described in detail in [29,32]. Results from [33], adapted according to [34], were used to estimate losses from outdoor paddocks into water, assuming a constant rate between $\mathrm{P}$ losses and the body mass (live-weight) of pigs on pasture (see Equation (S1) in the Supplementary Materials). P losses from manure storage, treatment, and spreading were assumed to be negligible and ignored [29]. All emission factors used are given in the Supplementary Material. All traits used for deriving the indicators of the pig unit's environmental impact are provided in Table 2. 
Table 2. Input data for the characterization of the environmental impact of organic pig systems.

\begin{tabular}{|c|c|}
\hline Category & Parameter \\
\hline $\begin{array}{l}\text { sow } \\
\text { performance }\end{array}$ & $\begin{array}{l}\text { number of weaned piglets per sow and year, replacement rate }(\%) \text {, live weight at slaughter } \\
(\mathrm{kg}) \text {, feed intake during gestation and lactation }(\mathrm{kg} / \mathrm{period}) \text {, duration of lactation (days) }\end{array}$ \\
\hline $\begin{array}{l}\text { weaner } \\
\text { performance }\end{array}$ & $\begin{array}{l}\text { weight at weaning }(\mathrm{kg}) \text {, piglet mortality }(\%) \text {, daily feed intake }(\mathrm{kg}) \text {, feed conversion rate } \\
\text { (kg feed } / \mathrm{kg} \text { live weight gain), duration of weaning period (days) }\end{array}$ \\
\hline $\begin{array}{c}\text { fattener } \\
\text { performance }\end{array}$ & $\begin{array}{l}\text { weight at beginning of fattening phase }(\mathrm{kg}) \text {, mortality }(\%) \text {, daily feed intake }(\mathrm{kg}) \text {, feed } \\
\text { conversion rate }(\mathrm{kg} \text { feed } / \mathrm{kg} \text { live weight gain), daily weight gain }(\mathrm{kg} / \text { day), live weight at } \\
\text { slaughter }(\mathrm{kg}) \text {, age at slaughter (days), duration of fattening period (days) }\end{array}$ \\
\hline diets & $\begin{array}{l}\text { diet composition (\% of individual feed ingredients), diet nutrient, i.e., crude protein }(\mathrm{CP}, \mathrm{g} / \mathrm{kg}) \\
\text { and phosphorus }(\mathrm{P}, \mathrm{g} / \mathrm{kg}) \text {, and metabolizable energy content }(\mathrm{MJ} / \mathrm{kg})\end{array}$ \\
\hline land use & on-farm crop production \\
\hline $\begin{array}{c}\text { animal } \\
\text { husbandry }\end{array}$ & $\begin{array}{l}\text { type of system, i.e., outdoor (OUT), partly outdoor (POUT), indoor (IN) with outside run, type } \\
\text { of floor (solid floor, slats / partly slatted, deep litter) }\end{array}$ \\
\hline manure & $\begin{array}{l}\text { manure type (liquid, solid), manure handling (cleaning frequency), manure storage (type and } \\
\text { duration), manure treatment (composting, anaerobic/aerobic digestion), type and distance of } \\
\text { spreading (wide spreading, injection), mean distance of manure transport to place of } \\
\text { spreading, crop rotation, and stocking rate (animals/ha) }\end{array}$ \\
\hline $\begin{array}{l}\text { bedding } \\
\text { quality }\end{array}$ & $\begin{array}{l}\text { very good: } 100 \% \text { of litter is clean, dry, and not mouldy } \\
\text { good: }>50 \% \text { of litter is clean, dry, and not mouldy } \\
\text { poor: }>50 \% \text { of litter is dirty, wet, or mouldy } \\
\text { very poor: } 100 \% \text { of litter is dirty, wet, or mouldy }\end{array}$ \\
\hline
\end{tabular}

Parameters to calculate the environmental impact from the production of all feedstuffs, except fishmeal and fish oil, were adopted from previous studies [35,36]. The nitrogen (N)-related part of feeds' $\mathrm{EP}$ was calculated by multiplying typical quantities of $\mathrm{N}$ applied in manure and commercial fertilizers on organic farms in Austria with typical $\mathrm{NO}_{3}-\mathrm{N}$ leaching factors identified in [37]. For P-losses from feed production, it was assumed that, on average, a surplus of $5 \%$ over plant requirements (according to yield) was applied and lost. The GWP of the rarely used components, fishmeal and fish oil, originate from [38]. The GWP, AP, and EP for monocalcium phosphate and mineral premixes are based on the Danish LCA food database [39].

The total feed consumption per animal, including bought-in-feedstuffs, was calculated from farm-specific data (based on daily consumption per animal, feed conversion rate, duration of the periods, average daily gains, etc.). For individual missing values, results from [40] and [41] were used in the fattening and the weaner stages, respectively. For farms lacking full records on the feed intake and feed conversion ratio, these values were estimated according to farm and animal category-specific dietary contents for $\mathrm{MJ} \mathrm{ME}, \mathrm{CP}$, and $\mathrm{P}$, and recommended nutrient requirements at the respective physiological stage [42]. Furthermore, the relative amount of digestible lysine per unit of energy (g/MJ NE) was calculated based on the online tool, Evapig [43], and compared to requirements at different stages [44]; a 10\% tolerance was accepted due to the uncertainty of NE and lysine content. Diets for growing and finishing pigs were classified as sufficient, deficient, or exceeding requirements (excess) using the content of digestible lysine relative to the NE content as an indicator. Feed components and feedstuffs were categorized as described in Table 3.

\subsubsection{Characteristics of the Husbandry Systems}

\section{Animal Performance, Production Data, and Feeding Characteristics}

Animal performance and production data, as well as feed characteristics, varied substantially within and between systems, see Supplementary Materials (Tables S4 and S5). In OUT-PCs, the number of piglets born and weaned per sow was lower than in the other systems, but the median age at culling was higher, and hence the replacement rate was lower in OUT. OUT-PCs showed lower mortality and 
heavier pigs at weaning. Some of the diverging characteristics, such as numerically smaller sows in OUT, are probably related to the use of local, traditional breeds (e.g., Cinta Senese, Tamworth). Median live weight $(\mathrm{kg})$ of slaughter pigs was $131.0 \mathrm{~kg}$ in IN, $117.0 \mathrm{~kg}$ in POUT, and $124.0 \mathrm{~kg}$ in OUT. Diet characteristics and amounts of feed used differed in many parameters between the husbandry systems. However, average metabolizable energy and crude protein contents were similar between systems for sow diets, and similar average metabolizable energy were recorded for weaners and finishing farms.

Table 3. Categorization of feed components and feedstuffs.

\begin{tabular}{cl}
\hline Feed Stuff Category & \multicolumn{1}{c}{ Component } \\
\hline animal or microbial origin & brewer's yeast, fish meal, fish oil, whey powder (sweet), whey concentrate \\
\hline compound feed & different compound feeds for growing and/or finishing pigs \\
\hline grains (cereals) & barley, maize, rye, oat, triticale, wheat \\
\hline high-protein by-products & $\begin{array}{l}\text { false flax seed cake, potato protein, rapeseed cake, rapeseed meal, } \\
\text { sunflower seed cake }\end{array}$ \\
\hline leguminous grains & fava beans, peas, soybean, soybean cake \\
\hline minerals & clay, mineral premix, monocalcium phosphate \\
\hline plant raw materials) & $\begin{array}{l}\text { alfalfa (lucerne) green meal or similar roughage, brewer's grains (dried), } \\
\text { grass cobs, rapeseed oil, spelt husks, sugar beet molasses, sunflower seed } \\
\text { oil, wheat bran, wheat starch }\end{array}$ \\
\hline supplementary compound feed & high-protein supplements \\
\hline
\end{tabular}

Housing (Floor Type) and Manure Management

The housing, and consequently the manure management, varied only between the individual PCs in IN and POUT, while in OUT, all animals were kept outdoors. Detailed information on housing (floor type) is provided for all animal categories in IN and POUT-PCs in the Supplementary Materials (Table S6). All animal categories in IN were kept on (partly slatted) concrete floors, with bedded lying areas. For POUT, $83 \%$ of PCs kept lactating sows outdoors throughout the year, and $45 \%$ kept dry sows outside, with a much lower proportion keeping weaners and fatteners outdoors.

The floor types for weaners and fatteners housed on POUT farms varied largely. Depending on the floor type, IN and POUT PCs produced either solid manure only or solid manure and slurry. In IN, $95.5 \%$ of the PCs generated a combination of solid manure and slurry, while only $4.5 \%$ had only solid manure. In POUT, the proportion of PCs with both solid manure and slurry was $69 \%$. In OUT, no manure was stored and handled.

The type and frequency of manure treatments by husbandry system are reported in the Supplementary Material (Table S7). In IN, $16.6 \%$ of PCs used aerobic digestion. Thirty percent of the POUT-PCs applied a treatment (composting, aerobic, or anaerobic digestion) to the slurry. Across all systems, most PCs did not treat the solid manure before application; composting was the only treatment found on $26.3 \%$ of IN- and $15.3 \%$ of POUT-PCs.

\subsection{Statistical Data Analysis}

All statistical analyses were performed with each individual PC as the statistical unit in SAS 9.2 and 9.3 (SAS-Institute, Cary, North Carolina, USA, 2008). Non-parametric Kruskal-Wallis tests were used for comparisons between husbandry systems. When significant effects $(p<0.05)$ were revealed in global tests, pairwise comparisons were performed using the Wilcoxon Two-Sample (Rank sum) test. $p$-Values were adjusted for multiple comparisons using Bonferroni correction. Additionally, to investigate associations between the environmental impact categories of AP, EP, and GWP and farm characteristics, Spearman rank correlations were calculated. Only those characteristics were included which were not directly considered in the LCA calculation, except for piglets weaned per sow per year [n, $1 \mathrm{yr}$ mean] and carcass weight [kg, $1 \mathrm{yr}$ mean]. 
Since AP, EP, and GWP did not significantly correlate with each other, they were subjected to a hierarchical cluster analysis using the average linkage method. Values were standardized using the procedure, STDIZE, in SAS using the mean as a location measure and the sample standard deviation as a scale measure. For this analysis, five outliers (2 IN, 2 POUT, 1 OUT) were excluded, as identified from boxplots, resulting in 59 PCs being included in the final cluster analysis. The number of clusters was based on R-Squared (SAS-Institute, 2008), Pseudo F, and Pseudo t2 statistics. Additionally, the average distance between the clusters was graphically checked in a dendrogram.

\section{Results}

\subsection{GWP, AP, and EP of the Three Husbandry Systems}

The total environmental impacts (AP, EP, and GWP) of the 64 PCs in the different husbandry systems are presented in Table 4 . Statistical comparison of the three pig husbandry systems with respect to GWP, AP, and EP revealed inconsistent results.

Table 4. Environmental impact (global warming, GWP; acidification potential, AP; eutrophication potential, EP) of organic pig production in three husbandry systems, IN, POUT, and OUT.

\begin{tabular}{ccccccccc}
\hline \multirow{2}{*}{ Parameter } & $\begin{array}{c}\text { Husbandry } \\
\text { System }\end{array}$ & $\begin{array}{c}\mathbf{n} \\
\mathbf{( P C )}\end{array}$ & Min. & Q25\% & Median & Q75\% & Max. \\
\hline \multirow{2}{*}{ GWP } & $\mathrm{kg} \mathrm{CO}_{2}$-eq/1000 kg live & IN & 24 & 1605 & 1860 & 2204 & 2347 & 2962 \\
& weight at slaughter & POUT & 30 & 1663 & 1997 & 2213 & 2407 & 3393 \\
& & OUT & 10 & 1470 & 1593 & 2210 & 2705 & 3480 \\
\hline \multirow{2}{*}{$\mathrm{AP}$} & \multirow{2}{*}{$\mathrm{kg} \mathrm{SO}_{2}$-eq/1000 kg live } & IN & 24 & 38.0 & 55.2 & $61.9^{\mathrm{a}}$ & 78.4 & 114.4 \\
& weight at slaughter & POUT & 30 & 37.8 & 47.0 & $51.9^{\mathrm{b}}$ & 61.0 & 88.4 \\
& & OUT & 10 & 34.8 & 38.4 & $55.4^{\mathrm{ab}}$ & 72.3 & 91.0 \\
\hline \multirow{2}{*}{$\mathrm{EP}$} & \multirow{2}{*}{$\mathrm{kg} \mathrm{PO}_{4}$-eq/1000 kg live } & IN & 24 & 13.6 & 18.2 & $21.6^{\mathrm{ab}}$ & 25.7 & 48.7 \\
& weight at slaughter & POUT & 30 & 13.3 & 17.8 & $20.1^{\mathrm{b}}$ & 25.1 & 43.2 \\
& & OUT & 10 & 17.8 & 19.9 & $28.7^{\mathrm{a}}$ & 36.8 & 46.2 \\
\hline
\end{tabular}

a,b Different superscript letters indicate differences between groups for which $p<0.05$ ( $p$-values adjusted according to Bonferroni correction for triple testing).

No significant differences were found regarding the GWP between systems. With 2204, 2213, and $2209 \mathrm{~kg} \mathrm{CO}_{2}$-eq per $1000 \mathrm{~kg}$ live weight at slaughter, the median estimate for the GWP was similar for the three systems, IN, POUT, and OUT $(p=0.934)$. Across systems, the PCs with the lowest and highest GWP were both found in OUT, and the variation in the GWP was numerically smaller in IN and POUT than in OUT.

In all systems, feed production most strongly contributed to the GWP, followed by animal housing (direct emissions originating from the animal and excreta inside houses), and, in IN and POUT, manure storage (Figure 1). Manure treatment and manure spreading contributed only a small percentage to the GWP in IN and POUT, while in OUT, manure is directly excreted onto the field by the animal and therefore is neither stored, treated, nor spread. Relative contributions of housing emissions tended to be lower in IN, whereas the relative contribution of manure storage was highest for this system. Consistently, the highest relative contribution of housing (including field deposition of manure) was found for OUT.

The median AP was significantly higher in IN $(61.9 \mathrm{~kg} \mathrm{SO}$-eq per $1000 \mathrm{~kg}$ live weight at slaughter) than in POUT (51.9 kg SO 2 -eq per $1000 \mathrm{~kg}$ live weight at slaughter; $p=0.006)$, mainly due to more $\mathrm{NH}_{3}$ arising from manure spreading in IN. In OUT, AP was numerically slightly higher than in POUT. Across systems, the individual PC with the lowest AP was found in OUT and the one with the highest AP was in IN. The variation (interquartile range) was smaller in POUT compared to IN and OUT.

Similar to GWP, feed production and animal housing contributed most to AP (Figure 1). The relative contribution of manure spreading in IN and POUT to both AP and EP was higher than the 
corresponding contributions to GWP. Regarding AP, IN showed higher relative amounts of $\mathrm{SO}_{2}$-eq originating from feed, housing of the animals (direct emissions), and, especially, manure storage and spreading. In POUT, some manure remains directly on the paddock and is not stored or spread on the field, thus leading to lower $\mathrm{AP}$ due to lower $\mathrm{NH}_{3}$ emissions. Manure spreading was the main explanation for differences in the AP between IN and POUT. An even higher difference was found between OUT and IN, again due to the lack of manure spreading in OUT.

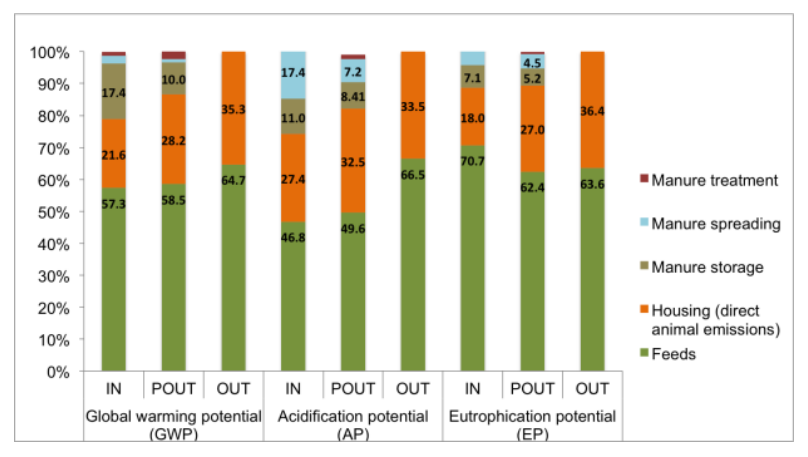

Figure 1. Mean relative contribution of the different sources to GWP, AP, and EP based on data from IN $(n=24)$, POUT $(n=30)$, and OUT $(n=10)$ production chains.

The median EP, expressed in $\mathrm{kg} \mathrm{PO}_{4}$-eq per $1000 \mathrm{~kg}$ of live weight at slaughter, was significantly higher in OUT than in POUT $(p=0.010)$, mainly due to more $\mathrm{PO}_{4}$-eq resulting from feed consumption and housing. Total EP of IN was similar to the EP of POUT, but did not differ significantly from OUT. Variation (interquartile range) in OUT was larger than in the other systems. Across all systems, the most important source of EP was feed production, followed by animal housing. In IN and POUT, manure storage, treatment, and spreading also contributed to EP, but to a lesser extent. The highest contribution of feed and housing regarding EP was found in OUT, which had a higher median feed conversion rate than POUT- or IN-PCs, and consequently needed more feed to achieve $1000 \mathrm{~kg}$ of slaughter weight.

When considering the environmental impact indicators (GWP, AP, EP) based on animal production stages, across all systems the fattening phase had the highest influence (between $68 \%$ and $74 \%$ of the totals), with little variation between the systems and impact indicators (Figure 2).

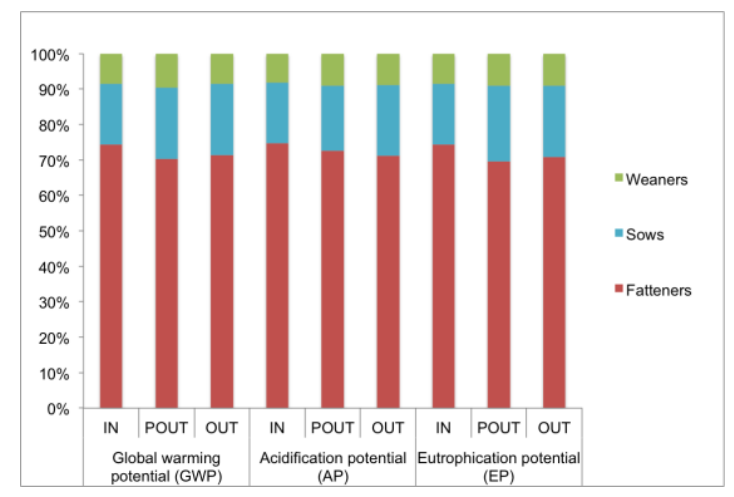

Figure 2. Mean relative contribution of the different animal categories to GWP, AP, and EP based on data from IN $(n=24)$, POUT $(n=30)$, and OUT $(n=10)$ production chains.

\subsection{Correlations between Farm Characteristics and Environmental Impacts}

Correlation coefficients of farm characteristics with environmental impact indicators are presented in Table 5. Two characteristics relating to size of the pig units (number of slaughtered pigs and livestock units per PC) negatively correlated with AP and EP, with larger PCs having lower AP and EP. The current number of sows on the farm, which also relates to farm size, was also negatively correlated with AP. 
Table 5. Coefficients of correlation (Spearman's Rho's) between farm characteristics (rows) and environmental impact indicators (columns) for 61 production chains (three production chains had to be excluded due to a missing animal category at the farm).

\begin{tabular}{|c|c|c|c|c|}
\hline \multicolumn{2}{|r|}{ Parameter } & GWP & AP & EP \\
\hline \multicolumn{2}{|c|}{ n sows [present at visit] } & ns & $-0.33^{* *}$ & ns \\
\hline \multicolumn{2}{|c|}{ slaughtered finishers $[\mathrm{n} / 1 \mathrm{yr}]$} & ns & $-0.30 *$ & $-0.31 *$ \\
\hline & ns & $-0.37^{* *}$ & $-0.30 *$ \\
\hline \multirow{2}{*}{\multicolumn{2}{|c|}{$\begin{array}{c}\text { piglets born per litter (life born }+ \text { still born) [n, } 1 \text { yr mean] } \\
\text { number of weaned piglets per sow per year }\end{array}$}} & ns & ns & $-0.44^{* * *}$ \\
\hline & & $-0.35^{* *}$ & $-0.27 *$ & $-0.37^{* *}$ \\
\hline \multicolumn{2}{|c|}{ carcass weight $[\mathrm{kg}, 1$ yr mean $]$} & ns & $0.30 *$ & $0.30^{*}$ \\
\hline \multicolumn{2}{|c|}{ age at culling [n farrowings] } & ns & ns & ns \\
\hline \multirow{2}{*}{\multicolumn{2}{|c|}{$\begin{array}{l}\text { Mastitis Metritis Agalactia (MMA) treatment of sows (\%) } \\
\text { percentage of bought-in feed for finishers (\%) }\end{array}$}} & ns & ns & ns \\
\hline & & ns & $-0.40^{* *}$ & ns \\
\hline \multirow{8}{*}{$\begin{array}{l}\text { relative contribution of } \\
\text { feed stuff category }(\%)\end{array}$} & grains (Cereals) & ns & ns & $0.29 *$ \\
\hline & leguminous crops & ns & ns & ns \\
\hline & high-protein by-products & ns & ns & $-0.26^{*}$ \\
\hline & others & ns & ns & ns \\
\hline & components of animal or microbial origin & ns & ns & ns \\
\hline & minerals & ns & ns & $-0.40^{* *}$ \\
\hline & compound feed & ns & ns & ns \\
\hline & supplementary compound feed & ns & ns & ns \\
\hline
\end{tabular}
ns: Not significant, ${ }^{*} p<0.05,{ }^{* *} p<0.01,{ }^{* * *} p<0.001$.

The total number of piglets born per litter negatively correlated with EP, whilst piglet numbers weaned per sow and year negatively correlated with all environmental impact indicators. The average final carcass weight correlated positively with AP and EP, while the percentage of bought-in feed in fattener diets was negatively associated with AP. Additionally, the relationship between the relative contribution of feedstuff categories to the diets and the environmental impact indicators was investigated, but associations were only found for EP. The relative contribution of the high-protein by-product feed and mineral supplements negatively correlated with EP, while the amount of grains correlated positively.

\subsection{Cluster Analysis Regarding Impacts of Organic Pig Husbandry Systems}

The hierarchical cluster analysis revealed two suitable classification levels, with five and four clusters, respectively. For statistical reasons (number of observations per cluster), the higher aggregation level, i.e., combining clusters 1 and 4 to cluster 1/4, was chosen. The number of PCs per husbandry system and cluster are shown in Table 6.

Table 6. Number of production chains per system (IN, POUT, OUT) in the four clusters identified.

\begin{tabular}{ccccc}
\hline \multicolumn{5}{c}{ Number of Production Chains Per System in Cluster } \\
\hline System & Cluster $\mathbf{1 / 4}$ & Cluster $\mathbf{2}$ & Cluster $\mathbf{3}$ & Cluster 5 \\
\hline Impact & Intermediate & Low & High & Highest \\
\hline IN & 5 & 8 & 9 & 0 \\
POUT & 13 & 10 & 5 & 0 \\
OUT & 4 & 3 & 0 & 2 \\
total & 22 & 21 & 14 & 2 \\
\hline \multicolumn{5}{c}{ * Clusters subjected to further statistical analysis. }
\end{tabular}

In Table 7 all clusters are presented: Cluster 2, representing 35.6\% of the total, on average, showed numerically the lowest environmental impacts (referred to as "low impact cluster" below). Cluster 1/4 can be considered as the "intermediate impact cluster", with values of AP, EP, and GWP between those of Cluster 2 and Cluster 3. Cluster 3 had higher median values for AP, EP, and GWP as compared 
to Cluster 1/4 and Cluster 2. Consequently, Cluster 3 can be described as the "high impact cluster". Cluster 5 resulted in overall highest environmental impacts, but due to the very small number of farms, included data are only presented descriptively, but not further considered in the analysis.

Table 7. Environmental impacts (GWP, AP, and EP) per $1000 \mathrm{~kg}$ of live weight at slaughter by cluster (total $\mathrm{N}=59$ production chains) (cluster 5 not subjected to further statistical tests is highlighted in grey).

\begin{tabular}{cccccccc}
\hline Parameter & Cluster Number & n (PC) & Min. & Q25\% & Median & Q75\% & Max. \\
\hline & $1 / 4$ & 22 & 2008 & 2153 & 2222 & 2405 & 2962 \\
GWP [kg CO -eq per 1000 kg & 2 & 21 & 1470 & 1668 & 1776 & 1906 & 2102 \\
live weight at slaughter] & 3 & 14 & 1977 & 2316 & 2348 & 2416 & 2695 \\
& 5 & 2 & 2705 & 2705 & 2908 & 3111 & 3111 \\
\hline & $1 / 4$ & 22 & 46.0 & 51.9 & 56.0 & 59.0 & 63.3 \\
AP [kg SO 2 -eq per 1000 kg & 2 & 21 & 34.7 & 40.0 & 47.0 & 50.9 & 59.1 \\
live weight at slaughter] & 3 & 14 & 69.5 & 72.1 & 77.3 & 81.2 & 88.2 \\
& 5 & 2 & 72.3 & 72.3 & 74.1 & 76.0 & 76.0 \\
\hline & $1 / 4$ & 22 & 15.8 & 19.7 & 21.1 & 24.6 & 29.1 \\
EP [kg PO 4 -eq per 1000 kg & 2 & 21 & 13.3 & 17.0 & 17.6 & 18.6 & 20.5 \\
live weight at slaughter] & 3 & 14 & 22.7 & 24.8 & 25.9 & 28.0 & 30.5 \\
& 5 & 2 & 36.8 & 36.8 & 37.5 & 38.1 & 38.1 \\
\hline
\end{tabular}

Generally, environmental impact indicators were predominantly influenced by emissions from feed and housing (direct emissions during animal keeping). Numerically, the low impact cluster had the lowest contributions from these sources and Cluster 5 the highest.

Regarding GWP, the intermediate and high impact clusters had relatively comparable values, which were slightly higher in the high impact cluster, but the contribution of the different sources to total GWP differed numerically; the intermediate impact cluster was characterized by higher amounts from feed and housing, while the contribution of manure storage and spreading was higher in the high impact cluster. Considering AP and EP, the main difference leading to numerically higher amounts in the high impact cluster compared to the intermediate impact cluster, were emissions from manure spreading (Figure 3).

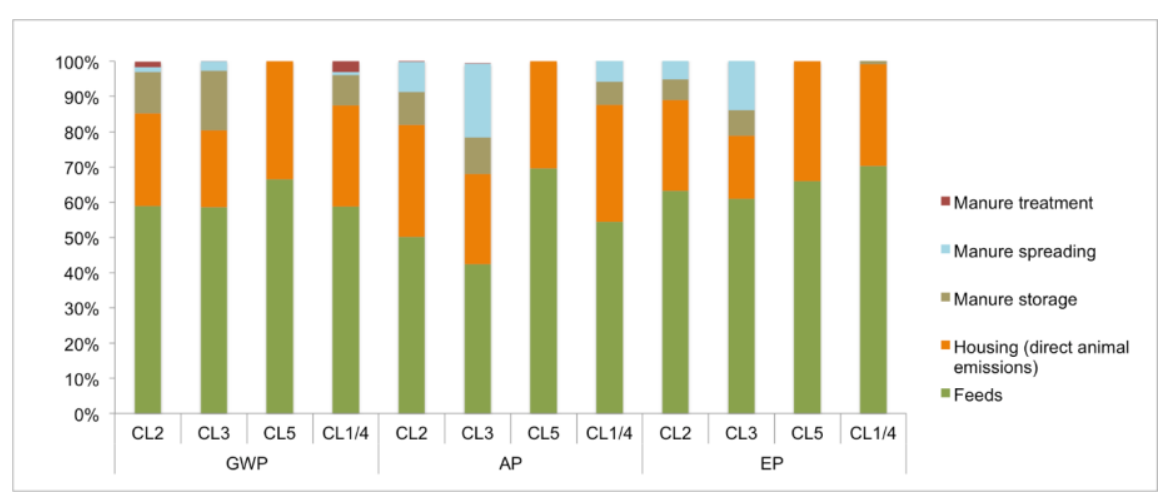

Figure 3. Mean relative contribution of the different sources to GWP, AP, and EP by cluster (total $n=59)$. CL2 = Cluster 2 (low environmental impact cluster, $n=21$ ), CL3 = Cluster 3 (high environmental impact cluster, $\mathrm{n}=14), \mathrm{CL} 5=$ Cluster $5(\mathrm{n}=2), \mathrm{CL} 1 / 4=$ Cluster $1 / 4$ (intermediate environmental impact cluster, $\mathrm{n}=22$ ).

Median numbers of sows, livestock units, and finishing pigs slaughtered per year per cluster ranged between 28 and 110, 38 to 121, and 324 to 859 , respectively. These characteristics relating to farm size were numerically lowest for the high impact cluster, while the highest values were found in the intermediate impact cluster. The values for the low impact cluster were between those for the intermediate and high impact cluster. There were, however, no statistical differences between impact clusters in these parameters (see Supplementary Materials, Table S8). 
The average weight of pigs at the end of the post-weaning period differed between clusters as shown in Table 8. In the intermediate impact cluster, pigs entering the finishing phase were heavier than in the high impact cluster $(p=0.012)$. Lower weights at the start of the fattening phase had a negative effect on environmental impact indicators. Feed conversion for fattening pigs in the low impact cluster was lower than in the intermediate and high impact clusters $(p<0.001)$. In line with this, the total amount of feed per finished pig was lower in the low impact cluster in comparison to the high impact cluster $(p<0.001)$ and to the intermediate impact cluster $(p=0.006$; Table 9$)$. Improved feed conversion and lower feed consumption in the low impact cluster had a beneficial effect on environmental impacts. However, mortality of finishers was higher in the low impact cluster than in the high impact cluster $(p<0.001$; Table 8$)$. The percentage of bought-in feed in finishing diets (Table 9) was lower for the high impact cluster in comparison to the low impact cluster $(p=0.000)$ and the intermediate impact cluster $(p<0.001)$. Additionally, in the low and high impact cluster, more leguminous grains were fed than in the intermediate impact cluster (Table 10).

Table 8. Characteristics of the animal categories by cluster.

\begin{tabular}{|c|c|c|c|c|c|c|c|c|}
\hline $\begin{array}{c}\text { Animal } \\
\text { Category/Parameter }\end{array}$ & $\begin{array}{l}\text { Cluster impact } \\
\text { Category [Cluster } \\
\text { Number] }\end{array}$ & $\begin{array}{c}\mathrm{n} \\
(\mathrm{PC})\end{array}$ & Min. & Q25\% & Mean & Median & Q75\% & Max. \\
\hline \multicolumn{9}{|l|}{ sows } \\
\hline \multirow{3}{*}{$\begin{array}{l}\text { piglets born per litter } \\
\text { (live born }+ \text { still born) } \\
\quad[n, 1 \text { yr mean }]^{1}\end{array}$} & low [2] & 19 & 12.0 & 12.1 & 13.2 & 13.3 & 14.0 & 14.5 \\
\hline & intermediate $[1 / 4]$ & 20 & 6.0 & 10.8 & 12.1 & 12.3 & 14.0 & 16.5 \\
\hline & high [3] & 13 & 8.0 & 12.0 & 12.8 & 13.3 & 14.0 & 14.5 \\
\hline \multirow{3}{*}{ 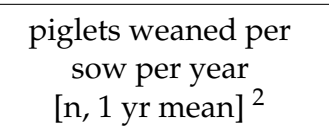 } & low [2] & 20 & 10.0 & 18.2 & 19.2 & 19.9 & 21.1 & 25.0 \\
\hline & intermediate $[1 / 4]$ & 22 & 10.0 & 16.0 & 18.3 & 19.0 & 21.0 & 23.8 \\
\hline & high [3] & 14 & 14.0 & 16.0 & 18.3 & 19.1 & 19.7 & 25.0 \\
\hline \multirow{3}{*}{$\begin{array}{c}\text { sow replacement rate } \\
{[\%, 1 \text { yr mean }]^{2}}\end{array}$} & low [2] & 20 & 12.0 & 26.0 & 31.8 & 30.5 & 35.0 & 50.0 \\
\hline & intermediate [1/4] & 22 & 8.0 & 20.0 & 32.5 & 28.0 & 45.0 & 87.0 \\
\hline & high [3] & 14 & 20.0 & 20.0 & 29.0 & 26.5 & 33.0 & 53.0 \\
\hline \multirow{3}{*}{$\begin{array}{l}\text { live weight at culling } \\
{[\mathrm{kg} \text { at culling }]^{2}}\end{array}$} & low [2] & 20 & 187 & 200 & 237 & 240 & 257 & 310 \\
\hline & intermediate [1/4] & 22 & 180 & 220 & 249 & 245 & 275 & 325 \\
\hline & high [3] & 14 & 197 & 200 & 234 & 233 & 253 & 277 \\
\hline \multicolumn{9}{|l|}{ Weaners } \\
\hline \multirow{3}{*}{$\begin{array}{l}\text { weight at weaning } \\
{[\mathrm{kg}, 1 \mathrm{yr} \text { mean }]^{2}}\end{array}$} & low [2] & 20 & 0.0 & 10.0 & 11.3 & 10.7 & 13.5 & 22.0 \\
\hline & intermediate [1/4] & 22 & 5.5 & 10.0 & 13.1 & 12.5 & 15.0 & 28.0 \\
\hline & high [3] & 14 & 8.0 & 10.0 & 11.5 & 10.9 & 12.5 & 22.0 \\
\hline \multirow{3}{*}{$\begin{array}{l}\text { weight at end of } \\
\text { post-weaning } \\
{[\mathrm{kg}, 1 \mathrm{yr} \text { mean }]^{2}}\end{array}$} & low [2] & 20 & 24.0 & 25.8 & 29.4 & $30.0^{\mathrm{ab}}$ & 30.0 & 42.0 \\
\hline & intermediate $[1 / 4]$ & 22 & 25.0 & 30.0 & 31.6 & $31.5^{b}$ & 35.0 & 40.0 \\
\hline & high [3] & 14 & 23.0 & 25.0 & 28.3 & $29.0^{a}$ & 30.0 & 34.0 \\
\hline \multirow{3}{*}{$\begin{array}{c}\text { mortality rate } \\
\text { weaners } \\
{[\%, 1 \text { yr mean }]^{2}}\end{array}$} & low [2] & 20 & 0.0 & 3.5 & 5.7 & 5.0 & 5.0 & 20.0 \\
\hline & intermediate $[1 / 4]$ & 22 & 0.0 & 1.0 & 3.2 & 3.0 & 5.0 & 10.0 \\
\hline & high [3] & 14 & 0.0 & 1.0 & 3.1 & 3.0 & 5.0 & 5.0 \\
\hline \multicolumn{9}{|l|}{ fattening pigs } \\
\hline \multirow{3}{*}{$\begin{array}{c}\text { live weight at } \\
\text { slaughter } \\
{[\mathrm{kg}, 1 \text { yr mean }]^{2}}\end{array}$} & low [2] & 20 & 104 & 112 & 124 & 117 & 129 & 165 \\
\hline & intermediate $[1 / 4]$ & 21 & 86 & 112 & 128 & 120 & 136 & 200 \\
\hline & high [3] & 14 & 116 & 121 & 131 & 129 & 140 & 150 \\
\hline \multirow{3}{*}{$\begin{array}{c}\text { mortality rate } \\
\text { fattening pigs } \\
{[\%, 1 \text { yr mean }]^{2}}\end{array}$} & low [2] & 20 & 1.0 & 1.5 & 2.9 & $3.0^{\mathrm{a}}$ & 4.0 & 5.0 \\
\hline & intermediate [1/4] & 21 & 0.0 & 1.0 & 1.9 & $2.0^{\mathrm{ab}}$ & 2.0 & 6.0 \\
\hline & high [3] & 14 & 0.0 & 0.0 & 1.0 & $1.0^{b}$ & 1.0 & 4.0 \\
\hline
\end{tabular}

${ }^{1}$ Number of observations differs from number of production chains, as each parameter was not always assessable for all farms; ${ }^{2}$ number of observations differ from number of production chains, as the environmental impact was calculated using mean values for missing animal categories for three farms (piglet production for two farms; fattening pigs for one farm); ${ }^{3}$ parameters that showed significant differences between clusters are printed in bold; ${ }^{a, b}$ different superscript letters indicate differences between groups $(p<0.05, p$-values adjusted according to Bonferroni correction for triple testing). 
Table 9. Dietary characteristics by cluster.

\begin{tabular}{|c|c|c|c|c|c|c|c|c|}
\hline $\begin{array}{l}\text { Animal Category/ } \\
\text { Parameter }{ }^{1}\end{array}$ & $\begin{array}{l}\text { Cluster Impact Category } \\
\text { [cluster Number] }\end{array}$ & $\begin{array}{c}n \\
(P C)\end{array}$ & Min. & Q25\% & Mean & Median & Q75\% & Max. \\
\hline \multicolumn{9}{|l|}{ sows } \\
\hline \multirow{3}{*}{$\begin{array}{l}\text { feed per sow } \\
{[\mathrm{kg} / \text { year }]}\end{array}$} & low [2] & 20 & 675 & 1028 & 1415 & 1458 & 1595 & 2053 \\
\hline & intermediate [1/4] & 22 & 827 & 1332 & 1603 & 1702 & 1834 & 2236 \\
\hline & high [3] & 14 & 1060 & 1203 & 1383 & 1385 & 1473 & 1946 \\
\hline \multicolumn{9}{|c|}{ average dietary content of } \\
\hline \multirow{3}{*}{$\mathrm{ME}[\mathrm{MJ} / / \mathrm{kg}]$} & low [2] & 20 & 9.6 & 11.9 & 12.1 & 12.5 & 12.9 & 13.1 \\
\hline & intermediate [1/4] & 22 & 12.0 & 12.3 & 12.7 & 12.7 & 12.9 & 13.7 \\
\hline & high [3] & 14 & 11.8 & 12.4 & 12.6 & 12.6 & 13.0 & 13.3 \\
\hline \multirow{3}{*}{$\mathrm{CP}[\mathrm{g} / \mathrm{kg}]$} & low [2] & 20 & 124 & 148 & 155 & 155 & 164 & 185 \\
\hline & intermediate [1/4] & 22 & 112 & 137 & 149 & 152 & 162 & 180 \\
\hline & high [3] & 14 & 133 & 146 & 150 & 151 & 157 & 165 \\
\hline \multirow{3}{*}{ total P $[\mathrm{g} / \mathrm{kg}]$} & low [2] & 20 & 3.0 & 4.7 & 5.2 & 5.5 & 5.9 & 7.8 \\
\hline & intermediate [1/4] & 22 & 3.1 & 4.5 & 5.4 & 5.8 & 6.1 & 6.5 \\
\hline & high [3] & 14 & 3.3 & 4.4 & 5.0 & 5.3 & 5.5 & 6.0 \\
\hline \multicolumn{9}{|l|}{ Weaners } \\
\hline feed per weaner & low [2] & 20 & 18 & 30 & 38 & 39 & 45 & 56 \\
\hline produced & intermediate $[1 / 4]$ & 22 & 12 & 33 & 43 & 38 & 50 & 111 \\
\hline$[\mathrm{kg} /$ weaner $]$ & high [3] & 14 & 20 & 30 & 37 & 36 & 45 & 59 \\
\hline \multicolumn{9}{|c|}{ average dietary content of } \\
\hline \multirow{3}{*}{$\mathrm{ME}[\mathrm{MJ} / / \mathrm{kg}]$} & low [2] & 20 & 9.5 & 12.5 & 12.4 & 12.8 & 13.1 & 13.4 \\
\hline & intermediate [1/4] & 22 & 12.0 & 12.6 & 12.9 & 12.9 & 13.2 & 13.6 \\
\hline & high [3] & 14 & 12.0 & 12.9 & 13.0 & 13.1 & 13.4 & 13.5 \\
\hline \multirow{3}{*}{$\mathrm{CP}[\mathrm{g} / \mathrm{kg}]$} & low [2] & 20 & 138 & 168 & 177 & 179 & 189 & 203 \\
\hline & intermediate [1/4] & 22 & 112 & 170 & 176 & 181 & 195 & 208 \\
\hline & high [3] & 14 & 147 & 172 & 180 & 182 & 188 & 208 \\
\hline \multirow{3}{*}{ total $\mathrm{P}[\mathrm{g} / \mathrm{kg}]$} & low [2] & 20 & 3.5 & 3.8 & 5.2 & 5.7 & 6.0 & 6.8 \\
\hline & intermediate [1/4] & 22 & 3.1 & 5.5 & 5.6 & 6.0 & 6.2 & 6.9 \\
\hline & high [3] & 14 & 3.5 & 4.7 & 5.5 & 5.5 & 5.8 & 8.9 \\
\hline \multicolumn{9}{|l|}{ Fattening pigs } \\
\hline \multirow{3}{*}{$\begin{array}{l}\text { feed per fattening } \\
\text { pig }[\mathrm{kg}]\end{array}$} & low [2] & 20 & 209 & 222 & 269 & $242^{a}$ & 322 & 378 \\
\hline & intermediate [1/4] & 21 & 159 & 266 & 381 & $337^{a b}$ & 385 & 981 \\
\hline & high [3] & 14 & 291 & 323 & 384 & $390^{b}$ & 443 & 494 \\
\hline \multirow{3}{*}{$\begin{array}{l}\text { percentage of } \\
\text { bought-in feed stuff } \\
\text { in fattener diets }\end{array}$} & low [2] & 18 & 20 & 58 & 79 & $100^{a}$ & 100 & 100 \\
\hline & intermediate [1/4] & 19 & 30 & 100 & 87 & $100^{a}$ & 100 & 100 \\
\hline & high [3] & 14 & 0 & 7 & 35 & $25^{b}$ & 69 & 100 \\
\hline \multirow{3}{*}{$\begin{array}{l}\text { fattening pig FCR } \\
\text { [kg feed/kg pig] }\end{array}$} & low [2] & 20 & 2.4 & 2.7 & 2.9 & $2.8^{a}$ & 3.0 & 3.3 \\
\hline & intermediate $[1 / 4]$ & 21 & 3.0 & 3.2 & 3.8 & $3.6^{b}$ & 4.2 & 6.0 \\
\hline & high [3] & 14 & 3.1 & 3.3 & 3.7 & $3.8^{b}$ & 4.0 & 4.6 \\
\hline \multicolumn{9}{|c|}{ average dietary content of } \\
\hline \multirow{3}{*}{$\mathrm{ME}[\mathrm{MJ} / / \mathrm{kg}]$} & low [2] & 20 & 9.5 & 12.5 & 12.3 & 12.8 & 12.9 & 13.2 \\
\hline & intermediate [1/4] & 21 & 12.0 & 12.6 & 13.0 & 12.9 & 13.2 & 14.5 \\
\hline & high [3] & 14 & 12.0 & 12.7 & 13.0 & 12.9 & 13.0 & 14.8 \\
\hline \multirow{3}{*}{$\mathrm{CP}[\mathrm{g} / \mathrm{kg}]$} & low [2] & 20 & 139 & 153 & 163 & 165 & 172 & 190 \\
\hline & intermediate [1/4] & 21 & 112 & 144 & 162 & 171 & 183 & 202 \\
\hline & high [3] & 14 & 118 & 153 & 157 & 158 & 164 & 177 \\
\hline \multirow{3}{*}{ total $\mathrm{P}[\mathrm{g} / \mathrm{kg}]$} & low [2] & 20 & 2.4 & 3.6 & 4.5 & 4.9 & 5.1 & 6.0 \\
\hline & intermediate [1/4] & 21 & 3.1 & 4.0 & 5.0 & 5.5 & 5.8 & 6.4 \\
\hline & high [3] & 14 & 3.3 & 4.0 & 4.6 & 4.8 & 5.1 & 6.0 \\
\hline
\end{tabular}


Table 10. Dietary proportion of feedstuff categories by cluster.

\begin{tabular}{|c|c|c|c|c|c|c|c|c|}
\hline Feed Category $^{1}$ & $\begin{array}{l}\text { Cluster Impact Category } \\
\text { [Cluster Number] }\end{array}$ & $\begin{array}{c}n \\
(\mathrm{PC})\end{array}$ & Min. & Q25\% & Mean & Median & Q75\% & Max. \\
\hline \multirow{3}{*}{ cereal grains } & low [2] & 19 & 0.0 & 50.0 & 53.2 & 61.8 & 67.8 & 74.5 \\
\hline & intermediate [1/4] & 21 & 0.0 & 50.0 & 53.8 & 65.0 & 71.4 & 90.0 \\
\hline & high [3] & 14 & 41.4 & 65.0 & 67.2 & 68.1 & 71.8 & 85.5 \\
\hline \multirow{3}{*}{$\begin{array}{l}\text { leguminous } \\
\text { grains }\end{array}$} & low [2] & 19 & 0.0 & 16.4 & 20.9 & $25.0 \mathrm{ab}$ & 27.5 & 31.6 \\
\hline & intermediate [1/4] & 21 & 0.0 & 7.5 & 16.3 & $17.4^{b}$ & 21.9 & 44.4 \\
\hline & high [3] & 14 & 14.5 & 20.5 & 26.0 & $23.1^{a}$ & 31.0 & 44.5 \\
\hline \multirow{3}{*}{$\begin{array}{l}\text { high-protein } \\
\text { by-products }\end{array}$} & low [2] & 19 & 0.0 & 2.0 & 5.3 & 4.7 & 8.4 & 13.1 \\
\hline & intermediate [1/4] & 21 & 0.0 & 0.0 & 3.3 & 1.1 & 4.2 & 13.8 \\
\hline & high [3] & 14 & 0.0 & 0.0 & 2.7 & 1.6 & 6.4 & 6.9 \\
\hline \multirow{3}{*}{ others } & low [2] & 19 & 0.0 & 0.0 & 7.2 & 3.0 & 6.8 & 80.2 \\
\hline & intermediate $[1 / 4]$ & 20 & 0.0 & 0.0 & 3.9 & 0.1 & 5.1 & 17.1 \\
\hline & high [3] & 14 & 0.0 & 0.0 & 1.0 & 0.0 & 1.1 & 5.1 \\
\hline \multirow{3}{*}{$\begin{array}{l}\text { components of } \\
\text { animal or } \\
\text { microbial origin }\end{array}$} & low [2] & 19 & 0.0 & 0.0 & 0.4 & 0.0 & 1.0 & 3.2 \\
\hline & intermediate $[1 / 4]$ & 21 & 0.0 & 0.0 & 2.3 & 0.0 & 0.0 & 42.3 \\
\hline & high [3] & 14 & 0.0 & 0.0 & 0.0 & 0.0 & 0.0 & 0.0 \\
\hline \multirow{3}{*}{ minerals } & low [2] & 19 & 0.0 & 2.0 & 2.6 & 2.7 & 3.1 & 5.4 \\
\hline & intermediate [1/4] & 21 & 0.0 & 0.0 & 1.6 & 1.6 & 2.8 & 5.6 \\
\hline & high [3] & 14 & 0.0 & 2.0 & 2.2 & 2.4 & 2.9 & 4.0 \\
\hline \multirow{3}{*}{ compound feed } & low [2] & 19 & 0.0 & 0.0 & 10.5 & 0.0 & 0.0 & 100 \\
\hline & intermediate [1/4] & 21 & 0.0 & 0.0 & 19.1 & 0.0 & 0.0 & 100 \\
\hline & high [3] & 14 & 0.0 & 0.0 & 0.0 & 0.0 & 0.0 & 0.0 \\
\hline \multirow{3}{*}{$\begin{array}{l}\text { supplementary } \\
\text { compound feed }\end{array}$} & low [2] & 19 & 0.0 & 0.0 & 0.0 & 0.0 & 0.0 & 0.0 \\
\hline & intermediate [1/4] & 21 & 0.0 & 0.0 & 0.0 & 0.0 & 0.0 & 0.0 \\
\hline & high [3] & 14 & 0.0 & 0.0 & 1.0 & 0.0 & 0.0 & 11.4 \\
\hline
\end{tabular}

${ }^{1}$ Parameters that showed significant differences between clusters are printed in bold; ${ }^{\mathrm{a}, \mathrm{b}}$ different superscript letters within columns indicate differences between groups $(p<0.05, p$-values adjusted according to Bonferroni correction for triple testing).

The high impact cluster showed a higher proportion of PCs feeding sufficient digestible lysine to finishing pigs, compared to the intermediate impact cluster $(64.3 \%$ vs. $6.3 \%$, respectively; $p=0.001$; Table 11). There were no differences in the proportion of deficient or excess diets for growing and finishing pigs, but the low impact cluster still showed a high proportion of diets with sufficient digestible lysine content $(41.2 \%)$. Across the growing and finishing diets, the low impact cluster showed the highest proportion of diets without deficient digestible lysine (82.4\%).

Table 11. Classification of animal categories by cluster according to deficient, excess, or sufficient proportions of digestible lysine in the grower and finisher diets; $\mathrm{N}=$ total number of production chains per cluster.

\begin{tabular}{cccccc}
\hline $\begin{array}{c}\text { Animal } \\
\text { Category }\end{array}$ & Status of Diet & $\begin{array}{c}\text { Cluster According to } \\
\text { Impact [Cluster Number] }\end{array}$ & $\mathbf{n ~}^{\mathbf{2}}$ & $\begin{array}{c}\text { Frequency } \\
\text { (n) }\end{array}$ & $\begin{array}{c}\text { Percentage } \\
\text { (\%) }\end{array}$ \\
\hline & dLys deficient & low [2] & 17 & 2 & 11.8 \\
& [<0.72 g & intermediate [1/4] & 15 & 6 & 40.0 \\
dLys/MJ NE] & high [3] & 14 & 3 & 21.4 \\
\cline { 2 - 6 } growers & dLys excess & low [2] & 17 & 4 & 25.5 \\
& [>0.88 g & intermediate [1/4] & 15 & 2 & 13.3 \\
& dLys/MJ NE] & high [3] & 14 & 4 & 28.6 \\
\cline { 2 - 6 } & dLys sufficient & low [2] & 17 & 11 & 61.7 \\
& [0.72-0.88 g & intermediate [1/4] & 15 & 7 & 64.7 \\
& dLys/MJ NE] & high [3] & 14 & 7 & 50.0 \\
\hline
\end{tabular}


Table 11. Cont.

\begin{tabular}{cccccc}
\hline $\begin{array}{c}\text { Animal } \\
\text { Category }^{\mathbf{1}}\end{array}$ & Status of Diet & $\begin{array}{c}\text { Cluster According to } \\
\text { Impact [Cluster Number] }\end{array}$ & $\mathbf{n ~}^{\mathbf{2}}$ & $\begin{array}{c}\text { Frequency } \\
\text { (n) }\end{array}$ & $\begin{array}{c}\text { Percentage } \\
\text { (\%) }\end{array}$ \\
\hline & dLys deficient & low [2] & 17 & 2 & 11.8 \\
& {$[<0.63 \mathrm{~g}$} & intermediate [1/4] & 16 & 7 & 43.8 \\
flinishers & high [3] & 14 & 3 & 21.4 \\
\cline { 2 - 6 } & dLys excess & low [2] & 17 & 8 & 47.1 \\
& [l>0.77 g & intermediate [1/4] & 16 & 8 & 50.0 \\
& dLys /MJ NE] & high [3] & 14 & 2 & 14.3 \\
& dLyfficient & low [2] & $\mathbf{1 7}$ & $\mathbf{7}$ & $\mathbf{4 1 . 2}^{\text {ab }}$ \\
& [0.63-0.77 g & intermediate [1/4] & $\mathbf{1 6}$ & $\mathbf{1}$ & $\mathbf{6 . 3}^{\mathbf{b}}$ \\
& dLys/MJ NE] & high [3] & $\mathbf{1 4}$ & $\mathbf{9}$ & $\mathbf{6 4 . 3}^{\mathbf{a}}$ \\
\hline
\end{tabular}

${ }^{1}$ Parameters that showed significant differences between clusters are printed in bold; ${ }^{2}$ classification of diets was not possible for all PCs; ${ }^{\text {a,b }}$ different superscript letters indicate differences between groups $(p<0.05, p$-values adjusted according to Bonferroni correction for triple testing).

\section{Discussion}

\subsection{General Discussion and Comparison with Other Studies}

Both hypotheses were confirmed: For all environmental impact categories, variation was greater within than between systems, with no distinct differences between husbandry systems regarding their environmental impact. Furthermore, farm characteristics contributing to environmental impact were identified, and they were mainly related to performance (e.g., piglets weaned per sow and year, fattening pig feed conversion ratio) and feed characteristics (e.g., percentage of bought-in feed stuff in fattener diets; see Section 4.2).

The selected classification was chosen according to [1], who found that specific characteristics (e.g., farm size, breeds, live-weights at slaughtering, etc.) of organic farms suggest this differentiation into the three husbandry systems. It may be used to inform the organic sector regarding the strengths and weaknesses of these three widely used systems' variants, and the results may serve as a basis for system-specific mitigation strategies. The large range of results indicates potential for improvement within all three systems. Cluster analysis was used to investigate further classification. It was interesting to find high, medium, and low impact clusters independently from husbandry systems, but with characteristics regarding feeding and performance, which are mainly affected by management decisions.

Comparing different LCA studies should always be done with caution due to differences in underlying methodology, assumptions, and chosen system boundaries [45]. The present study addressed, for the first time, the environmental impact of different organic pig husbandry systems based on data obtained from 64 individual farrow-to-finish production chains across several European countries. In accordance with [9], there was a high variation in environmental impact among farms in the present study, indicating that individual farm characteristics highly influenced the outcome.

Other authors report comparable GWP, but rather different AP and EP (Table 12). A possible reason is that the GWP originating from the main emission source feedstuffs does not differ widely, except for those loaded with high emissions from land use change. However, in organic systems, comparably low emissions occur from land use change. Contrarily, emission factors regarding AP and EP show a higher variation between animals kept indoors or outdoors. Additionally, methodological differences between studies (e.g., system boundaries, emission factors, type of allocation) could have contributed to the great variation.

In general, most of our results are within the ranges reported in the literature, e.g., as provided in a review of six comparable LCA studies of pork products [4] (Table 12). The authors also found a large variation, especially regarding acidification and eutrophication potential. 
Our results are particularly comparable to results reported by [15], who used a similar methodology and system boundaries for an evaluation of 15 pig farming systems from five European countries. For each pig farming system, data from five to 10 farms were obtained from surveys, and systems were categorized into conventional, adapted conventional, traditional, and organic. Feed production contributed less to EP in organic systems than in the others [15]. In the present study, the results regarding EP (medians ranging from 20.1 to $28.7 \mathrm{~g} \mathrm{PO}_{4}$-eq per $\mathrm{kg}$ live weight) exceed the values for organic farms found by [15]; $16 \mathrm{~g} \mathrm{PO}_{4}$-eq), and are in the range reported for conventional systems. The higher EP in the present study may, on the one hand, be due to a poorer median feed conversion ratio in IN, POUT, and OUT than found by [15]. On the other hand, due to the assumption of a $5 \% \mathrm{PO}_{4}$-surplus over yield-related plant requirements, our methodological approach might have resulted in higher $\mathrm{PO}_{4}$-emission estimates from feed production.

Regarding AP, [15] found higher medians for organic systems than for POUT and OUT in the present study. The even higher median AP found in IN compared to [15] may be attributed to higher emissions from manure management (storage and spreading) as well as from feed, which resulted mainly from a poorer feed conversion ratio in fatteners in the present study compared to [15].

\subsection{Factors Influencing the Environmental Impacts}

In terms of the relative impact of feed on GWP, AP, and EP, results presented herein agree with those of other LCA studies [10,22,33,46,47]. Dolman et al. [9] calculated correlations between farm characteristics and environmental impact: All environmental indicators correlated positively with feed intake and dietary composition. Likewise, and in accordance with [22], who identified the feed conversion ratio in fatteners as the parameter with the greatest influence on LCA outcomes, in the present study, the feed conversion ratio was significantly lower for fatteners in the low impact cluster. The percentage of bought-in feed for fattener diets (\%) was weakly negatively correlated with AP. This might indicate that these feeds either were loaded with relatively low AP or the feeds contributed to a better balanced diet and hence an improved feed conversion.

Regarding the relative contribution (\%) of feedstuff categories to the environmental impact indicators, significant correlations were only found for EP. The proportion of high-protein by-products and minerals negatively correlated with EP, while the proportion of cereal grains was positively correlated. This might indicate that high-protein by-products and minerals contribute to a better balanced diet. Furthermore, for fed by-products, a relatively low proportion of impacts from crop production and processing is allocated to the co-product feed (e.g., molasses or oil cakes), and a rather high share to the main product, e.g., sugar or oil.

The average fattener carcass weight $(\mathrm{kg})$ was positively correlated with AP and EP, as during the fattening stage a large proportion of emissions arise. Towards the end of the fattening period the amount of feed needed for $1 \mathrm{~kg}$ of weight gain increases in comparison to earlier growing stages [42].

Furthermore, reproductive performance, especially the number of piglets born alive per litter, has been described as an important influencing factor $[23,48]$. However, as for all associations found in the present study, only weak correlations regarding sow fertility and the environmental impacts were found. The number of total born (still and live born) piglets per litter negatively correlated with EP. However, the correlation coefficient again indicated only a weak relationship, therefore, the results do not allow for strong conclusions. Emissions originating from the sows are allocated to their offspring, and, therefore, higher litter sizes may be regarded as beneficial if all piglets survive and grow adequately. However, in light of the effect of litter size on piglet mortality [20], the focus should be on an adequate litter size, with robust and viable piglets. This suggestion fits to the number of piglets weaned per sow and year being negatively associated with all environmental impact indicators, which may indicate that farms with good management and productivity are at an advantage. 
Table 12. Greenhouse gas emissions (GWP, $\left.\mathrm{kg} \mathrm{CO}_{2}-\mathrm{eq} / \mathrm{FU}\right)$, acidification potential ( $\mathrm{AP}, \mathrm{g} \mathrm{SO}$-eq/FU), and eutrophication potential $\left(\mathrm{EP}, \mathrm{g} \mathrm{PO}_{4}\right.$-eq/FU) from selected LCA studies on pig production $(\mathrm{FU}=$ Functional unit).

\begin{tabular}{|c|c|c|c|c|c|}
\hline Source & System/Study Case & FU & GWP & AP & EP \\
\hline present results & IN (indoor) & $\mathrm{kg}$ live weight & 2.2 & 61.9 & 21.6 \\
\hline present results & POUT (partly outdoor) & $\mathrm{kg}$ live weight & 2.2 & 51.9 & 20.1 \\
\hline present results & OUT (outdoor) & $\mathrm{kg}$ live weight & 2.2 & 55.4 & 28.7 \\
\hline [4] & $\begin{array}{l}\text { literature review: range across different } \\
\text { conventional systems }\end{array}$ & kg pork & $3.9-10$ & $43-741$ & up to 20 \\
\hline [49] & organic (outdoors) & $\mathrm{kg}$ live weight & 4.0 & 92.8 & 4.1 \\
\hline [15] & $\begin{array}{l}\text { range across conventional, adapted } \\
\text { conventional, traditional, organic }\end{array}$ & kg live weight & $2.2-3.4$ & $44-57$ & $16-34$ \\
\hline [15] & organic & $\mathrm{kg}$ live weight & 2.4 & 57 & 16 \\
\hline$[24]^{1,2}$ & conventional, base scenario & $\mathrm{kg}$ live weight & 2.4 & 44.8 & 16.1 \\
\hline [10] & good agricultural practice & $\mathrm{kg}$ live weight & 2.3 & 21 & 44 \\
\hline [10] & 'Label Rouge' & $\mathrm{kg}$ live weight & 3.5 & 23 & 17 \\
\hline
\end{tabular}

${ }^{1}$ Results were recalculated to the functional unit of $1 \mathrm{~kg}$ of live weight by using the carcass yield mentioned in the studies; ${ }^{2}$ recalculated excluding the slaughter process.

Two farm characteristics describing the size of the pig units (number of slaughtered pigs, livestock units per PC) negatively correlated with AP and EP, with larger PCs having lower AP and EP. The current number of sows per PC was also weakly negatively correlated with AP, in line with the results for other farm size-related characteristics. These results may indicate that larger farms who are more efficient in managing their pigs, eventually connected with better trained farm staff. Similarly, negative correlations were found between the average number of fattening pigs and environmental impact indicators in [9], but this relationship is not considered as causal and may have been related to potentially better management in larger farms.

\subsection{Limitations of the Method and Uncertainties}

The present study used primary data from a non-representative sample of farms instead of modelled data based on assumptions. Therefore, sensitivity analyses, which are used for specific scenarios, were not applied here. Besides the influence of the PC-specific characteristics, LCA results depend on underlying methodological assumptions (e.g., emission factors for different floor types, allocation approach [49]). The degree of uncertainty for estimates revealed from these assumptions might vary between PCs, and estimates may therefore not be fully appropriate for the diverse husbandry systems in organic pig farming. A Monte Carlo analysis for the calculation of uncertainties of primary data as well as emission factors, describing the uncertainty areas of GWP, AP, and EP results, was not applied in the present study. In future studies on organic pig production, an analysis of the uncertainties with data from a representative sample of farms should be implemented. In addition, expanded system boundaries (including, for instance, the impacts of infrastructure) should be considered in future studies.

In case of emissions from feed production, uncertainty also arises from the fact that all countries' estimates were based on data for organic feed production in Austria. This approach was considered as the best option, as comprehensive region-specific data for the production of organic feedstuffs is not available and calculations of these would have been beyond the project resources.

Furthermore, farm-specific primary data, such as the feed conversion ratio, may be a source of uncertainty. The calculation of the feed conversion ratio is based on feed use ( $\mathrm{kg}$ feed fed per day) as reported by the farmers; losses of feed, occurring especially outdoors, were probably not taken into consideration by some farmers. Therefore, the calculated feed conversion ratio might be higher (i.e., poorer) than the true feed conversion ratio. However, in terms of environmental impact, the amount of feed should include feed losses. 
These limitations offer possible improvements for future studies. As the limitations concern all husbandry systems, they are not expected to affect the analysis of differences between husbandry systems. Furthermore, LCA takes numerous aspects into account; if weaknesses concern single aspects, this does not reduce the meaningfulness of the calculation. Finally, it must be mentioned that, despite these limitations, the data available for the present PC-specific cradle-to-farm gate LCA with a high number of organic pig farms included and taking different husbandry systems into account are unique.

\section{Conclusions}

Regarding environmental impact, a substantial variation was found between individual PCs. The ranking of the husbandry systems was not consistent regarding environmental impact; whereas the (median) GWP was similar in all systems; POUT had less AP than IN, and less EP than OUT.

The huge variation among PCs indicates that LCAs based on mean values of model scenarios will not necessarily be representative for individual farms, which may be subsumed in the modelled scenario. This reflects the importance of farm specific cradle-to-farm-gate assessments, rather than generalized scenarios for identifying the extent and the main sources of environmental impact in the different husbandry systems (IN, POUT, OUT).

In all husbandry systems, PCs with low environmental impacts were found, indicating that IN and POUT as well as OUT may be managed in an environmentally friendly way. However, a lack of consistent differences between husbandry systems, as well as results from cluster analysis, indicate that factors other than the husbandry systems affect the environmental impact of organic pig production.

Feeds generally constitute an important source for environmental impact, with the feed conversion ratio of fattening pigs being particularly important. Based on cluster analysis, an appropriate dietary digestible lysine content as well as buying in feedstuffs for supplementation of protein or minerals appears to be beneficial for a low environmental impact.

Furthermore, manure management (storage and spreading) was identified as a main source of emissions. Measures, such as covering slurry tanks and direct application of manure to the soil, offer mitigation options.

The results indicate that an overall good farm management and adequate productivity reduces the environmental impacts, and hence optimization of management should be the focus irrespective of the production system.

Supplementary Materials: The following are available online at http:/ / www.mdpi.com/2071-1050/10/10/3796/s1, Equation S1: P-losses into water bodies, Table S1: Emission factors for $\mathrm{NH}_{3}, \mathrm{~N}_{2} \mathrm{O}, \mathrm{N}_{2}$ and $\mathrm{NO}_{3}$ in outdoor paddocks, Table S2: Emission factors for housing and manure management systems depending on floor type and manure type, litter quality, storage period, spreading according to Rigolot et al. [29], Table S3: Characteristics of the animal production stages by system, Table S4: Characteristics of dietary nutrient content and feed consumption by system. The values reflect an average dietary content over all diets fed to the animal group. FCR $=$ Feed conversion rate, $\mathrm{n}=$ Number of production chains, Table S5: Percentages of floor type for lactating and pregnant sows, weaners and fattening pigs kept in the systems indoor (IN) and partly outdoor (POUT), Table S6: Type and frequency of manure treatment by system, Table S7: Cluster characteristics regarding number of sows on PC at farm visit, average number of slaughtered fattening pigs/year and number of livestock units (LSU).

Author Contributions: G.R. provided a draft manuscript, which was revised and edited by S.H., S.E., C.W. and C.L., G.B., J.Y.D., W.Z. additionally reviewed advanced versions of the manuscript. All authors approved the final version of the manuscript. G.R., D.B., R.B., B.F. and A.P. collected data. G.R., S.H., G.B., R.B., J.Y.D., M.M. and W.Z. developed the methodological approach and conducted the analysis; J.Y.D. and S.H. provided the software. Conceptualization and funding acquisition of the project included D.B., S.D., J.Y.D., S.E., B.F., M.M., A.P. and C.L.

Funding: This research was funded by the FP7 ERA-Net, CORE Organic II project "ProPIG", i.e. the national CORE Organic II funding agencies of Austria, Switzerland, United Kingdom, Italy, France, Denmark, Germany, Czech Republic.

Acknowledgments: The authors would like to thank all involved farmers and the ProPIG partners Tine Rousing, University of Aarhus in Denmark and Gudrun Illmann, Czech University of Life Sciences Prague.

Conflicts of Interest: The authors declare no conflict of interest. 


\section{References}

1. Früh, B.; Bochicchio, D.; Edwards, S.; Hegelund, L.; Leeb, C.; Sundrum, A.; Werne, S.; Wiberg, S.; Prunier, A. Description of organic pig production in Europe. Org. Agric. 2014, 4, 83-92. [CrossRef]

2. Lernoud, J.; Willer, H. Current statistics on organic agriculture worldwide: Organic area, producers, markets and selected crops. In The World of Organic Agriculture. Statistics and Emerging Trends 2015; Willer, H., Lernoud, J., Eds.; IFOAM: Bonn, Germany; FiBL: Frick, Switzerland, 2015; pp. 32-116. ISBN 978-3-03736-271-6.

3. Goodland, R. Livestock and Climate Change: What if the Key Actors in Climate Change Are... Cows, Pigs and Chicken? Worldwatch Institute: Washington, DC, USA, 2009.

4. De Vries, M.; de Boer, I.J.M. Comparing environmental impacts for livestock products: A review of life cycle assessments. Livest. Sci. 2010, 128, 1-11. [CrossRef]

5. Gerber, P.J.; Steinfeld, H.; Henderson, B.; Mottet, A.; Opio, C.; Dijkman, J.; Falcucci, A.; Tempio, G. Tackling Climate Change through Livestock-A Global Assessment of Emissions and Mitigation Opportunities; Food and Agriculture Organization of the United Nations: Rome, Italy, 2013.

6. Jacques, S. Science and animal welfare in France and European Union: Rules, constraints, achievements. Meat Sci. 2014, 98, 484-489. [CrossRef] [PubMed]

7. FAO. SAFA Sustainability Assessment of Food and Agriculture Systems Guidelines Version 3.0; Food and Agriculture Organization of the United Nations: Rome, Italy, 2014.

8. Guinée, J.B.; Gorrée, M.; Heijungs, R.; Huppes, G.; Kleijn, R.; Koning, A.; de Oers, L.; van Wegener Sleeswijk, A.; Suh, S.; Udo de Haes, H.A.; et al. Handbook on Life Cycle Assessment. Operational Guide to the ISO Standards; Kluwer Academic Publishers: Dordrecht, The Netherlands, 2002.

9. Dolman, M.A.; Vrolijk, H.C.J.; de Boer, I.J.M. Exploring variation in economic, environmental and societal performance among Dutch fattening pig farms. Livest. Sci. 2012, 149, 143-154. [CrossRef]

10. Basset-Mens, C.; van der Werf, H.M.G. Scenario-based environmental assessment of farming systems: The case of pig production in France. Agric. Ecosyst. Environ. 2005, 105, 127-144. [CrossRef]

11. Halberg, N.; Hermansen, J.E.; Kristensen, I.S.; Eriksen, J.; Tvedegaard, N.; Petersen, B.M. Impact of organic pig production systems on $\mathrm{CO} 2$ emission, $\mathrm{C}$ sequestration and nitrate pollution. Agron. Sustain. Dev. 2010, 30, 721-731. [CrossRef]

12. Olea, R.; Guy, J.; Edge, H.; Stockdale, E.A.; Edwards, S.A. Pigmeat supply chain: Life Cycle Analysis of contrasting pig farming scenarios. Asp. Appl. Biol. 2009, 95, 91-96.

13. Williams, A.G.; Audsley, E.; Sandars, D.L. Determining the Environmental Burdens and Resource Use in the Production of Agricultural and Horticultural Commodities; Main Report. Defra Research Project IS0205; Cranfield University and Defra: Bedford, UK, 2006.

14. Jakobsen, M.; Preda, T.; Kongsted, A.; Hermansen, J. Increased Foraging in Outdoor Organic Pig Production-Modeling Environmental Consequences. Foods 2015, 4, 622-644. [CrossRef] [PubMed]

15. Dourmad, J.Y.; Ryschawy, J.; Trousson, T.; Bonneau, M.; Gonzàlez, J.; Houwers, H.W.J.; Hviid, M.; Zimmer, C.; Nguyen, T.L.T.; Morgensen, L. Evaluating environmental impacts of contrasting pig farming systems with life cycle assessment. Animal 2014, 8, 2027-2037. [CrossRef] [PubMed]

16. IFOAM. The IFOAM Norms for Organic Production and Processing Version 2014; IFOAM: Bonn, Germany, 2014; ISBN 978-3-944372-10-5.

17. Algers, B.; Blokhuis, H.J.; Bøtner, A.; Broom, D.M.; Costa, P.; Domingo, M.; Greiner, M.; Hartung, J.; Koenen, F.; Müller-Graf, C.; et al. Scientific opinion of the Panel on Animal Health and Welfare on a request from the European Commission on species-specific welfare aspects of the main systems of stunning and killing of farmed carp. EFSA J. 2009, 1013. [CrossRef]

18. The European Parliament and the Council of the European Union. Regulation (EU) 2018/848 of the European Parliament and of the Council of 30 May 2018 on Organic Production and Labelling of Organic Products; The European Parliament and the Council of the European Union: Brussels, Belgium, 2018.

19. Edwards, S.A.; Prunier, A.; Bonde, M.; Stockdale, E.A. Special issue-Organic pig production in Europe-Animal health, welfare and production challenges. Org. Agric. 2014, 4, 79-81. [CrossRef]

20. Prunier, A.; Dippel, S.; Bochicchio, D.; Edwards, S.; Leeb, C.; Lindgren, K.; Sundrum, A.; Dietze, K.; Bonde, M. Characteristics of organic pig farms in selected European countries and their possible influence on litter size and piglet mortality. Org. Agric. 2014, 4, 163-173. [CrossRef] 
21. Eriksen, J.; Hermansen, J.E.; Strudsholm, K.; Kristensen, K. Potential loss of nutrients from different rearing strategies for fattening pigs on pasture. Soil Use Manag. 2006, 22, 256-266. [CrossRef]

22. Reckmann, K.; Krieter, J. Environmental impacts of the pork supply chain with regard to farm performance. J. Agric. Sci. 2015, 153, 411-421. [CrossRef]

23. Garcia-Launay, F.; van der Werf, H.M.G.; Nguyen, T.T.H.; Le Tutour, L.; Dourmad, J.Y. Evaluation of the environmental implications of the incorporation of feed-use amino acids in pig production using Life Cycle Assessment. Livest. Sci. 2014, 161, 158-175. [CrossRef]

24. Nguyen, T.L.T.; Hermansen, J.E.; Mogensen, L. Fossil energy and GHG saving potentials of pig farming in the EU. Energy Policy 2010, 38, 2561-2571. [CrossRef]

25. The British Standards Institution. Publicly Available Specification. PAS 2050: 2011 Specification for the Assessment of the Life Cycle Greenhouse Gas Emissions of Goods and Services; British Standards Institution: London, UK, 2011.

26. Jespersen, L.M.; Baggesen, D.L.; Fog, E.; Halsnæs, K.; Hermansen, J.E.; Andreasen, L.; Strandberg, B.; Sørensen, J.T.; Halberg, N. Contribution of organic farming to public goods in Denmark. Org. Agric. 2017, 7, 243-266. [CrossRef]

27. Kool, A.; Blonk, H.; Ponsioen, T.; Sukkel, W.; Vermeer, H.M.; De Vries, J.W.; Hoste, R. Carbon Footprints of Conventional and Organic Pork: Assessment of Typical Production Systems in the Netherlands, Denmark, England and Germany; Wageingen UR: Wageningen, The Netherlands, 2009.

28. IPCC. Guidelines for National Greenhouse Gas Inventories; Eggleston Buendia, L., Miwa, K., Ngara, T., Tanabe, K.S., Eds.; IPCC: Geneva, Switzerland, 2006.

29. Rigolot, C.; Espagnol, S.; Pomar, C.; Dourmad, J.Y. Modelling of manure production by pigs and $\mathrm{NH}_{3}, \mathrm{~N}_{2} \mathrm{O}$ and $\mathrm{CH}_{4}$ emissions. Part I: Animal excretion and enteric $\mathrm{CH}_{4}$, effect of feeding and performance. Animal 2010, 4, 1401-1412. [CrossRef] [PubMed]

30. Wenzel, H.; Hausschild, M.; Alting, L. Environmental Assessment of Products: Methodology, Tools and Case Studies in Product Development; Chapman \& Hall: London, UK, 1997; Volume 1.

31. Nemecek, T.; Kägi, T. Life Cyce Inventories of Swiss and European Agricultural Production Systems; Final Report Ecoinvent Report v2.0., No. 15; Agroscope Reckenholz-Taenikon: Zürich and Dübendorf, Switzerland, 2007.

32. Brandhofer, R. Umweltwirkungen Biologischer Schweinehaltung: Vergleich Zweier Haltungssysteme auf Basis des Treibhausgas-Potenzials Sowie Einer Stickstoff und Phosphorbilanz. Master's Thesis, University of Natural Resources and Life Sciences, Vienna, Austria, 2014.

33. Basset-Mens, C.; van der Werf, H.M.G.; Robin, P.; Morvan, T.; Hassouna, M.; Paillat, J.M.; Vertès, F. Methods and data for the environmental inventory of contrasting pig production systems. J. Clean. Prod. 2007, 15, 1395-1405. [CrossRef]

34. Dourmad, J.Y.; Physiology of Adaptation, Animal Nutrition and Health, INRA, Saint-Gilles, France. Personal communication, 2013.

35. Hörtenhuber, S.; Lindenthal, T.; Amon, B.; Markut, T.; Kirner, L.; Zollitsch, W. Greenhouse gas emissions from selected Austrian dairy production systems-Model calculations considering the effects of land use change. Renew. Agric. Food Syst. 2010, 25, 316-329. [CrossRef]

36. Hörtenhuber, S.J.; Lindenthal, T.; Zollitsch, W. Reduction of greenhouse gas emissions from feed supply chains by utilizing regionally produced protein sources: The case of Austrian dairy production. J. Sci. Food Agric. 2011, 91, 1118-1127. [CrossRef] [PubMed]

37. Kolbe, H. Wasserbelastung in Abhängigkeit von der Landnutzung. Available online: http://orgprints.org/ $801 /$ (accessed on 19 October 2018).

38. Samuel-Fitwi, B.; Meyer, S.; Reckmann, K.; Schroeder, J.P.; Schulz, C. Aspiring for environmentally conscious aquafeed: Comparative LCA of aquafeed manufacturing using different protein sources. J. Clean. Prod. 2013, 52, 225-233. [CrossRef]

39. LCA Food database. Aalborg University and 2.-0 LCAconsultants. 2007. Available online: http://www. lcafood.dk/ (accessed on 19 Oct 2018).

40. Leeb, C.; Bernardi, F.; Winckler, C. Einführung und Monitoring von BetriebsEntwicklungsPlänen (BEP) Tiergesundheit und Wohlbefinden in Österreichischen Bioschweinebetrieben; Institut für Nutztierwissenschaften: Vienna, Austria, 2010.

41. Bayern, L. Schweinefütterung am Ökobetrieb II_Fütterungsversuche, Fütterungsempfehlungen; LfL Bayern: Poing, Germany, 2011. 
42. Kirchgessner, M.; Roth, F.X.; Schwarz, F.J.; Stangl, G. Tierernährung. Leitfaden für Studium, Beratung und Praxis, 13th ed.; DLG Verlag: Frankfurt, Germany, 2011.

43. EvaPig ${ }^{\circledR}$. A Calculator of Energy, Amino Acid and Phosphorus Values of Ingredients and Diets for Growing and Adult Pigs. Available online: http:/ / www.evapig.com (accessed on 19 October 2018).

44. Alibert, L. Besoins Alimentaires des Animaux en Fonction du Stade Physiologique. Available online: http:/ / www.itab.asso.fr/downloads / porc-bio/cahier_porc_0.pdf (accessed on 10 Dec 2014).

45. Lammers, P.J. Life-cycle assessment of farrow-to-finish pig production systems: A review. CAB Rev. Perspect. Agric. Vet. Sci. Nutr. Nat. Resour. 2011, 6, 1-8. [CrossRef]

46. Pelletier, N.; Lammers, P.; Stender, D.; Pirog, R. Life cycle assessment of high- and low-profitability commodity and deep-bedded niche swine production systems in the Upper Midwestern United States. Agric. Syst. 2010, 103, 599-608. [CrossRef]

47. Alig, M.; Grandl, F.; Mieleitner, J.; Nemecek, T.; Gaillard, G. Life Cycle Assessment of Beef, Pork and Poultry; Executive Summary; Reckenholz-Tänikon: Zürich, Switzerland, 2012.

48. Dalgaard, R.; Halberg, N.; Hermansen, J.E. Danish Pork Production-An Environmental Assessment; University of Aarhus: Tjele, Denmark, 2007; Volume 82.

49. Mackenzie, S.G.; Leinonen, I.; Ferguson, N.; Kyriazakis, I. Accounting for uncertainty in the quantification of the environmental impacts of Canadian pig farming systems Supplementary Material. J. Anim. Sci. 2015, 93, 3130-3143. [CrossRef] [PubMed]

(C) 2018 by the authors. Licensee MDPI, Basel, Switzerland. This article is an open access article distributed under the terms and conditions of the Creative Commons Attribution (CC BY) license (http:/ / creativecommons.org/licenses/by/4.0/). 